\title{
CULTURAL EMBEDDEDNESS OF FAMILY BUSINESS SUCCESSION. THE PERSPECTIVE OF NEXT GENERATION
}

\author{
Anna Bąkiewicz* iD https://orcid.org/0000-0002-7991-3931
}

\begin{abstract}
Background. The succession of family business has become the topic most often investigated within the family business $(\mathrm{FB})$ research. As we would like to understand the phenomena we need to recognize its specificity, mechanism of operation, determinants and consequences. In this case, a range of determinants of the process has been investigated so far. But, the flood of publications seems to focus on specific issues, leaving aside some important aspects of the problem.
\end{abstract}

Research aims. The purpose of the research is to summarize up to date knowledge on the determinants of the succession, and identify possible gaps in research, and thus potential areas for future inquiry. We concentrate on the culture prevailing in the community the firms operate in as a potentially significant factor determining the behavior of players involved in succession.

Methodology. The discussion undertaken in the paper is theoretical, based on deduction. The determinants of the process of succession are synthetized on the base of literature review. As there is no succession without successor, we concentrate on the younger generation perspective and try to cover the complexity of the issues involved.

Findings. We show important gaps in the research on family business succession, and point at culture embeddedness of the businesses, and the large promising area of intercultural comparative studies for our understanding of succession. We also indicate the legitimacy of a broader view on management issues by setting the problems in a specific cultural environment. The synthesis suggests the necessity of research on cultural determinants of succession, based on comparative analysis of cases from different cultural background. Moreover, it rises doubts if regularities of an organization operations observed in one cultural background would have universal value.

Keywords: family firms, succession, successors, national culture, next generation, commitment, intergenerational communication.

JEL Codes: L26.

\footnotetext{
* Społeczna Akademia Nauk. E-mail: abakiewicz@san.edu.pl.
} 


\section{INTRODUCTION}

The aim of the study is to diagnose our knowledge on the role of community culture on the successor' approach to family business (FB). It is an element of broader examination of the succession in family firms that has become the most investigated issue of $\mathrm{FB}$ activities. The literature survey is to provide a conceptually sound framework to develop our understanding of cultural determinants of successor's commitment to family business.

Drawing on the existing literature, we can say that perspective of next generation is very important for the succession in FB. No wonder the investigations of the successor-related factors have been quite numerous. And, quite many elements of the successor readiness for the succession have already been identified. And, although it is widely recognized in social sciences that examinations of both internal and external factors are necessary for understanding any subject, there is still not enough research on the impact of the outside determinants on the process of succession, the willingness of the successor included (Karima \& Habib, 2012). So, in order to gain a deeper understanding of successor approach to family business we try to include cultural embeddedness of FB operations into the research on succession. Having in mind the problems with operationalization of the cultural aspects of business operation, we also search for the methods of investigation that would potentially bring both theoretically and practically sound conclusions.

\section{THERE IS NO SUCCESSION WITHOUT SUCCESSOR}

The matter of succession has long been an area of interest in the FB literature (Barnes \& Hershon, 1976; Handler, 1994; Kuratko et al., 1993; Marjański \& Sułkowski, 2011; Ward, 2011). The perspective of the next generation on taking over family business is quite popular in FB research. It is commonly recognized that successor is an important stakeholder and he/she must effectively interact with other participants (e.g., family members, current incumbent, employees) in order to ensure support and understanding (de Pontet et al., 2007). Many researchers have suggested a number of desirable successor attributes that might be important for effective succession. 
Venter, Boshoff and Maas (2005) in their study on successor-related factors in small and medium FB pointed at three groups of main factors determining succession:

1. the preparation level of the successor (readiness);

2. the willingness of the successor to take over the business;

3. the quality of the relationship between the incumbent and successor.

Such a simple delimitation goes back to the classic elements determining manager's behavior: ability and propensity (Ansoff, 1984). Le Breton-Miller, Miller and Steier (2004) also proposed two major successor-related factors determining successful succession: successor abilities and successor motivation. The third point would be specific to FB as it corresponds with the interpersonal relations within family and business (Venter, Boshoff \& Maas, 2005).

\section{The preparation level of the successor (readiness)}

For an effective FB succession, a potential successor should have abilities to meet the strategic plans of the business such as education, technological skills, managerial skills, and financial management skills (Brockhaus, 2004; De Massis et al., 2008). The readiness of the successor - defined as a preparedness, ability or competences of the successor and/or successor capability in terms of competence and experience is the term that is used to describe the desirable features of a successor (Déniz Déniz \& Cabrera-Suárez, 2005; Sharma $\&$ Rao, 2000). There are many other elements of successor readiness, such as: training received from the incumbent, work experience (outside the firms) and entry level position (Amran \& Ahmad, 2010; Brockhaus, 2004; Chaimahawong \& Sakulsriprasert, 2012; De Massis et al., 2008; de Pontet et al., 2007; Morris et al., 1997; Pyromalis \& Vozikis, 2009; Sharma \& Rao, 2000; Sharma, 2004; Van der Merwe et al., 2009; Venter et al., 2005; Więcek-Janka et al., 2015).

Personality also plays an important role in the process of family business succession. According to Robbins and Judge (2012, p. 169), "personality refers to enduring characteristics that describe an individual's behavior". There is a long list of desirable successor attributes and personality characteristics: creativity, independence, integrity, intelligence, self-confidence, entrepreneurship and/or propensity to risk taking (Amran \& Ahmad, 2010; 
Brockhaus, 2004; Chaimahawong \& Sakulsriprasert, 2012; Chrisman et al., 1998; de Pontet et al., 2007; Griffeth et al., 2006; Handler, 1994; Lambrecht, 2005; Sharma, 2004; Sharma \& Rao, 2000; Van der Merwe, Venter \& Ellis, 2009). De Massis, Chua and Chrisman (2008) also pointed at the importance of the character and values based on integrity are the most important attribute of a potential successor. In their quantitative study, Chaimahawong and Sakulsripraert (2012) show that personal factors have the highest impact on the succession process in the family business with the impact level of 0.469 .

\section{The willingness of the successor to take over the business}

There are quite many elements that make up a propensity of a successor to take over the family business. The will and commitment, motivation and personal needs of a successor - all are being considered as important in the process of family business succession (Chrisman et al., 1998; De Massis et al., 2008; Georgiou \& Vrontis, 2013; Morris et al., 1997; Pyromalis \& Vozikis, 2009; Sharma \& Rao, 2000).

The idea of commitment has been always important in the human resource literature (Meyer \& Allen, 1991). Meyer and Herscovitch (2001), Bozer, Levin and Santora (2017) define commitment as a force, and/or frame of mind that that compels an individual towards a course of action aiming at one or more goals. Commitment is defined also as active participation in accomplishing tasks (Więcek-Janka et al., 2015). From the theory of organization we know that employees want to remain in an organization, believing that it is the right thing to do, that they are happier, more satisfied, more self-directed, healthier, more engaged and more willing to exert discretionary effort on behalf of the organization than when they are uncommitted or feel that they have to remain (Meyer \& Allen, 1991). A family's commitment to the business refers to the extent to which family members desire the perpetuation of the business in the family (Sharma, Chrisman \& Chua, 2003; Sharma \& Irving, 2005). Commitment is also defined as successor's willingness to take over the business (Déniz Déniz \& Cabrera-Suárez, 2005; Goldberg, 1996; Nordqvist et al., 2013; Venter et al., 2005).

Sharma and Irving (2005) identified four types of successor's willingness, depending on the background: 
- affective - based on desire (a perceived desire arising from the identification with the family needs),

- normative - based on obligation, based on tradition and/ or under pressure (a perceived sense of obligation towards the family),

- calculative - based on opportunity costs (a perceived sense of opportunity costs involved),

- imperative - based on need (a perceived need due to a lack of alternative career choices).

The most popular usage of the term "commitment" is consistent with affective commitment. It has the strongest positive correlation with desirable work behaviors, followed by normative commitment (Birley, Ng \& Godfrey, 1999; Cabrera-Suárez \& Santana, 2012; Zellweger et al., 2011).

The next generation's commitment is an essential condition for effective succession (Barach \& Ganitsky, 1995; Cadieux, 2007; Helsen et al., 2017; De Massis et al., 2008; Dyck et al., 2002; Evert et al., 2015; Morris et al., 1997; Pyromalis \& Vozikis, 2009; Sharma et al., 2003; Sharma et al., 2001; Sułkowski, 2005; Venter et al., 2005). Chrisman, Chua and Sharma (1998) concluded that integrity and commitment to business were considered the most essential attributes of successors. Cabrera-Suárez and Martin-Santana (2012) stated that commitment of the successor is more important for the success than technical skills. The quantitative results proved that the successor's commitment to take over the ownership of a family business positively affects the succession process in terms of satisfaction (p-value 0.047) and effectiveness ( $\mathrm{p}$-value 0.05) (Pyromalis \& Vozikis, 2009). It is because committed successors show willingness to develop a professional career in FB (Cabrera-Suárez \& Martín-Santana, 2012; Sharma \& Irving, 2005; Venter et al., 2005). On the other hand, a reluctant successor may not co-operate in the leadership transition (Goldberg \& Wooldridge, 1993) and misalignments of the successor's career interests with the business will increase agency costs (Eisenhardt, 1989; Sharma et al., 2001).

Moreover, the motivation of the successor is also important for the results of the succession (Barry, 1975; Cespedes \& Galford, 2004; Chrisman et al., 1998; Dumas, et al., 1995; Goldberg \& Wooldridge, 1993; Le Breton-Miller et al., 2004; Neubauer, 2003; Venter et al., 2005). Motivation refers to "the process that account[s] for an 
individual's intensity, direction and persistence of effort towards attaining a goal" (Robbins \& Judge, 2012, p. 236).

To ensure effective succession it is important that the personal needs of a successor are in line with that of the business (Venter et al., 2005). The business must meet the needs of the successor's life stage, lifestyle and available alternative sources of employment (Griffeth et al., 2006). As Stavrou (1999) says, successor's intentions to join or not the family business were related to individual needs, goals, skills, and abilities. Therefore, the readiness of the successor and his/her willingness to take over the business are interrelated (Bozer et al., 2017).

\section{The quality of the relationship between the incumbent and successor}

The importance of the quality of the relationship between the incumbent and successor to the process of the family business succession is well recognized (Cabrera-Suárez et al., 2001; Chaimahawong \& Sakulsriprasert, 2012; De Massis et al., 2008; de Pontet et al., 2007; Georgiou \& Vrontis, 2013; Goldberg, 1996; Griffeth et al., 2006; Handler, 1992; Kelly et al., 2000; Malone, 1989; Sułkowski, 2005). Even though each family member - the spouses, parents, adult children, and other relatives, has a role to play in the process of family business succession, the founder performs multiple roles in governing and managing the family business and he/she makes the most important executive decisions, also for the succession. The literature suggests that harmony, consensus and the quality of the relationship between the incumbent and the successor are all essential for the succession.

All the above mentioned, successor related factors have been identified as important for the succession in FB. The common feature of the methodology applied in this kind of investigations is that we receive a kind of list of requirements or expectations determining a successful succession. In such a demanding approach, the mechanism and/or the background of occurrence of specific conditions usually remains outside the area of examination. 


\section{MULTI-LEVEL MODELS OF SUCCESSION}

As the canons of general systems theory suggest (Von Bertalanffy, 1972), the interconnectedness of related subsystems is critical to understanding the overall system functionality. This approach justifies the inquiry of all the possible factors that might influence the successor's approach to FB. Here, following the classic Kotler and Armstrong (2011) approach we can point at macro-environment that consists of demographic, economic, technological, political and cultural factors as well as to natural forces. As the external environment factors are as a rule uncontrollable, it poses a special challenge for the firm as it cannot modify them but has to take them in to account in its operations.

Drawing from the existing literature some external elements that might be important for the successor willingness to take over a business can be identified. Le Breton-Miller, Miller and Steier (2004) have agreed that there are quite many important factors that operate indirectly and may be uncontrollable. They built a unique model in which the relations between family context, social context, industry context, the successor and incumbent have been interconnected. Handler (1994) have constructed 4-level concept of approach to succession: the individual level, the group level, the firm level, and the environmental level. The individual level considers personal attributes, attitudes, perspectives, behaviors and expectations. The group level focuses on the relationships and influences of family members on the succession. The firm level deals with the interaction of ownership transfer and/or succession on firm level dimension. Environmental level examines the external environment which influences business operations. In their model of succession, De Massis, Chua and Chrisman (2008) include the following factors: individual, relation factors, financial and cultural context. The latest category "...includes factors associated with changes in the economic environment in which the family business operates" (De Massis et al., 2008, p. 190). Chondrakis, Sigalas, Zaharopoulos and Vozikis (2006) summarize factors affecting succession mentioned in the literature. And, among fourteen market factors - competition and uncertainty of the environment - are the only external aspects, mentioned as the last one. Cultural influence in the model is pointed out indirectly as a culture of organization. 
The above attempts to include the entirety of the factors that can shape the succession process, point at necessity of complex approach to the issue. What is more, in all those models the external environment factors are more or less identified with the market/industry influence, whereas the macro environment element is considered indirectly.

\section{THE INFILTRATION OF FB RESEARCH WITH VARIOUS ASPECTS OF CULTURE}

The idea that culture is a central ingredient of economic behavior goes back to at least Max Weber (1905) who in his classical work argued that cultural background could be a powerful force behind the economic development. Hofstede (1980) defines culture simply as "the collective programming of the mind which distinguishes the members of one human group from another... [and] includes systems of values". Hofstede also says that people build organizations according to their values, and societies are composed of institutions and organizations that reflect the dominant values within their culture. The latter is responsible - among others, for motivation that influences behavior of individuals in a group. As culture determines preferences of an individual it also affects the economic behavior of the individual as the choice is a fundament of economic activity. Hofstede encouraged scientists to explore more than one level of social reality. And, in the research on organizational behavior close attention has been paid to the issues of individualism and collectivism, composing one of the six cultural dichotomies defined by Hofstede. The relation between the above aspects of culture in management is still one of the key problems that remain unsolved (Sułkowski, 2008).

Following the approach to culture applied in management studies (Kostera, 1996; Sułkowski, 2008; Thompson \& Luthans, 1990) we can point at the culture as an internal variable (organizational culture). It arises as an effect of the organization's operation and the research concerns mainly its creation and development, typology and relationships with the effectiveness of the entire organization (Sulkowski, 2008). It has already been stated that the organizational culture of family firm plays an important role in determining the success of the business beyond the first generation (Dyer, 1988; 
Sułkowski, 2013). The culture is also an external variable as it refers to national styles of management and the regional/local embeddedness of FB activity. As Ward (2000) says, national culture has a unique impact on the family that formulate the concepts of family business ownership and management.

In management studies the external embeddedness of an organization is often identified within context ${ }^{*}$ that refers to the settings of the phenomenon of interest (Cappelli \& Sherer, 1991; Johns, 2006). An organization or a family is a context for an individual. Similarly, economic, political, social, geographical, technological and cultural environment provide background for an enterprise. At a micro level, the business culture may deceive or encourage the successor to take over the business. At a macro level, the national or regional culture, demographics, education etc. may affect the succession as well. Nordqvist, Wennberg, Bau and Hellerstedt (2013) state that studying the context of FB can enrich our knowledge on particular elements of business operation, succession included. Agarwal, Kumar and D'Souza (2016, p. 55) concluded their meta-analysis on career choice in FB: "(...) there are still areas of potential research like contextual studies for India, understanding of the relevant factors influencing career choices, impact of socio-cultural factors, impact of societal influence on individual preferences, and even primogeniture with the increased influence of women in family businesses" .

The issue of cultural determinants of successor commitment could draw some lessons from the literature on entrepreneurship. The latter is extremely rich as far as culture understood as a determinant of entrepreneurial behavior is concerned (Glinka, 2008). Numerous individual and external factors have already been identified. There are some similarities here with the issue of carrier choice, as the latter is determined by three factors (Dyer, 1986; Kibler, 2013): individual (demographic and psychographic); social (family support, culture) and economic factors. And there is an

* The cultural background of the organizational behavior is also present in the idea of two cultural paradigms (contexts): high and low, as introduced by Hall (2003). He builds the dichotomy on the social structure and communication within society. In high cultural context, with non-verbal communication and identification with a group of people as the fundaments of social structure, interpersonal relations become of key importance for decision making and business operation. In low cultural context, the formal relations and open verbal communication and dominates economic decisions and business. Professional activity is separated from informal relations. 
extensive literature on the subject of national approach to entrepreneurship, starting from Inglehart (1988) and numerous studies based on quantification of cultural characteristics of nations (Bakkiewicz, 2018; Tripopsakul, 2018) that delineate entrepreneurial differences between notions.

The investigation on specificity of FB constitutes the core of family business research if only because it justifies the treatment of the population as a separate research object. No wonder the topic has been widely studied, and as a result, the interrelations between family culture and business operations are quite easily recognized. (Marjański \& Sułkowski, 2019; Sułkowski, 2013). It has already been shown that cultural values of a country/region lead to the diversity of the operations of family firms worldwide, succession planning and proceeding included. Numerous studies have supported the hypothesis on the important impact of culture prevailing in the local environment on the decisions undertaken in FB, so it is clear that family has significant role in imprinting its culture on the FB culture (Bozer et al., 2017; Kepner, 1983). The comparative analysis of FB in different countries has confirmed the potential of such investigations. Schmitt and Frese (2011) have found clear differences between family involvement onto FB in China and Germany. The specificity of family culture in Asia and the regional differences have been identified as having large potential to enrich our knowledge on cultural background of FB activities (Sharma \& Chua, 2013). Similarly, Birley, Ng and Godfrey (1999) have argued that culture affects the attitude of the owner towards involving the family in the business.

\section{CULTURE IN THE RESEARCH ON SUCCESSION}

As far as succession is concerned we know that culture infiltrates the firm operations through the family relations and in this way indirectly determines the process of succession (Aronoff \& Ward, 2011). We know that the more cohesive and adaptable the family culture, the greater the probability of the family accepting the succession change (Lee, 2006), changing values of the younger generation reflects their commitment to FB (Safin, 2007) and that the incorporation of cultural factors into decisions relating to the succession increases the chances of successful intergenerational transfer (Boyd 
et al., 2014). Pawlak (2014) found that entrepreneurial experience of a family and the image of an entrepreneur in a community are important for successors commitment to FB.

Relatively, much attention in FB literature on succession has been devoted to the issue of gender and birth-order as cultural factors that might shape to process of succession (Hadryś-Nowak \& Więcek-Janka, 2016; Harveston et al., 1997; Vera \& Dean, 2005). We know that daughters were excluded in the succession of family business, due to the fact that male successors were usually preferred. Sometimes the eldest son - no matter his competences or willingness, becomes the successor (Amran \& Ahmad, 2010; Stavrou, 1999; Schröder et al., 2011; Tatoglu et al., 2008). What is more, due to the modernization and/or professionalization of $\mathrm{FB}$, either daughters or younger sons are now selected for succession more often than in the past (Amran \& Ahmad, 2010; Brockhaus, 2004; Sharma \& Rao, 2000; Stavrou, 1999). Chrisman, Chua, and Sharma (1998) have discovered that gender and birth order were ranked the least important for succession.

There is extensive research that describes the influence of national cultures on succession attitudes (Kuratko et al., 1993; Lee et al., 2003), tendencies to adopt succession plans (Goto, 2006; Howorth \& Ali, 2001) and prevalence of successful successions (Afghan \& Wiqar, 2007; Levenburg et al., 2003; Mierzal et al., 2017). The differences in succession planning, process and satisfaction are being partly explained here by various cultural factors such as individualism, risk averseness and long-term orientation.

De Alwis (2016) has discovered that in Sri Lanka, where Buddhist and Hindu cultural environments prevail, people tend to concentrate on religious work as they become older, which favors smooth transfer of ownership in FB. Royer, Simons, Boydand and Rafferty (2008) argue that Japanese culture promotes the idea of transforming individuals into family insiders to enable an occurrence of internal succession. In contrast to Anglo-American cultures, in Portugal, less educated, less experienced, and less qualified sons are preferred over better educated daughters (Howorth \& Ali, 2001). Zellweger, Sieger and Halter (2011) claim that in Hungary, the founder option is preferred to any other careers; in Germany, the employment option is preferred to succession; and in New Zealand, a career path is strongly preferred. Morck and Yeung (2003) state that family firms 
in the formerly planned economies of Central and Eastern Europe may differ from American and Western European family businesses. Decker, Heinrichs, Jaskiewicz and Rau (2017) identified the influence of cultural background on the next generation's interest in taking over the business in South Asian family businesses. In Chinese family business transitions, Confucian values, e.g., respectful family relationships are related with stronger acceptance of succession decisions (Yan \& Sorenson, 2006). Mierzal, Ritz, Torres and Bergfeld (2017) have discovered differences in planning, process and long-term effects of succession between FB in Mexico and Germany. The visible variances in the successor's approach to taking over the FB have been identified. The dissimilarities have been associated also with cultural differences.

The aforementioned research belongs to a narrow group of studies that try to combine the successor's approach to the business with particular cultural characteristics of the community they operate in. What is missing in them is quite a common practice in succession research of referring to external, cultural or macroeconomic factors which can potentially explain what could not have been demonstrated in the study. The difficulty may arise from the fact that "Culture is a concept that is 'burdened' theoretically and empirically. It creates a vast 'family of words', which makes operationalization very difficult" (Sułkowski, 2008, p. 9). In fact, while culture foundation is widely accepted, research aimed at identifying specific mechanisms and the relationship between culture and succession is still rare.

\section{CONCLUSIONS}

As we tighten the loop on the research on the successor-related factors, we manage to identify an important niche in our understanding of the problems regarding succession. Mainly, our knowledge on the mechanism of both operation and importance of culture as a determinant of successor approach to FB is highly unsatisfactory, which is not because not enough research that has been performed in the matter. This is all the more surprising since cultural references in succession literature are very often referred to. However, the issue is rarely analyzed in detail. In other words, culture is one 
of the external elements that are often referred to in the subject literature, but they are rarely incorporated into the investigation in a considerate manner.

Moreover, a vast majority of the published work on firm succession are single-region or single-industry studies and they investigate the succession in Anglo-Saxon countries most often. The importance of cultural embeddedness provokes reservations about possible generalization across countries. It implies our doubts on whether the mechanisms identified in one country might also work in others. It seems that future research should aim at enrichment of our understanding of cultural background of succession even if only because it might generate a need of making certain adjustments in the ways succession process is prepared.

\section{REFERENCES}

Afghan, N. \& Wiqar, T. (2007). Succession in Family Businesses of Pakistan: Kinship Culture and Islamic Inheritance Law. CMER Working Paper, No. 07-54.

Agarwal, R., Kumar, A. \& D'Souza, K. (2016). Issues in Career Choices of Successors in Family Businesses: Perspective from Literature Review. Journal of Applied Management and Investments, vol. 5(1), 1-19.

Amran, N.A. \& Ahmad, A.Ch. (2010). Family Succession and Firm Performance among Malaysian Companies. International Journal of Business and Social Science, 1(2), 193-203.

Ansoff, H.I. (1984). Implanting strategic management. Englewood Cliffs, N.J.: Prentice/Hall International.

Aronoff, C. \& Ward, J. (2011). Family Business Values. How to Assure a Legacy of Continuity and Success. A Family Business Publication.

Barach, J.A. \& Ganitsky, J.B. (1995). Successful Succession in Family Business. Family Business Review, 8(2), 131-155.

Barnes, L.B. \& Hershon, S.A. (1976). Transferring power in the family business. Harvard Business Review, 54(4), 105-114.

Barry, B. (1975). The development of organization structure in the family firm. Journal of General Management, Autumn, 42-60.

Bakkiewicz, A. (2018). The Determinants of Entrepreneurship in Poland the Experiences of Post-communist Era. Przedsiębiorczość i Zarzqdzanie, 19/10/3, 41-56.

Birley, S., Ng, D. \& Godfrey, A. (1999). The family and the business. Long Range Planning, 36(6), 598-608. 
Boyd, B., Botero, I.C. \& Fediuk, T.A. (2014). Incumbent Decisions about Succession Transitions in Family Firms: A Conceptual Model. International Journal of Financial Studies, 2, 335-358, doi:10.3390/ijfs2040335.

Bozer, G., Levin, L. \& Santora, J.C. (2017). Succession in family business: multisource perspectives. Journal of Small Business and Enterprise Development, 24(4), 753-774, https://doi.org/10.1108/JSBED-10-2016-0163.

Brockhaus, R.H. (2004). Family business succession: suggestions for future research. Family Business Review, 17(2), 165-177, doi:10.1111/j.1741-6248.2004.00011.x.

Cabrera-Suárez, M.K., De Saá-Pérez, P. \& García-Almeida, D. (2001). The succession process from a resource and knowledge-based view of the family firm. Family Business Review, 14, 37-46.

Cabrera-Suárez, M.K. \& Martín-Santana, J.D. (2012). Successor's commitment and succession success: dimensions and antecedents in the small Spanish family firm. International Journal of Human Resource Management, 23(13/1), 2736-2762.

Cadieux, L. (2007). Succession in small and medium-sized family businesses: Toward a typology of predecessor roles during and after instatement of the successor. Family Business Review, 20(2), 95-109.

Cappelli, P. \& Scherer, P.D. (1991). The Missing Role of Context in OB: The Need for a Meso-Level Approach. Research in Organizational Behavior, 13, 55-110.

Cespedes, F.V. \& Galford, R.M. (2004). Succession and failure. Harvard Business School Case Study. Harvard Business Review, June, https://hbr. org/2004/06/succession-and-failure (Accessed: $3^{\text {rd }}$ September 2019).

Chaimahawong, V. \& Sakulsriprasert, A. (2012). Family Business Succession and Post Succession Performance: Evidence from Thai SMEs. International Jour nal of Business and Management, 8(2), 19-28, doi: 10.5539/ijbm.v8n2p19.

Chondrakis, G., Sigalas, C., Zaharopoulos, A. \& Vozikis, G.S. (2006). The Key Factors Affecting Family Business Succession. Innknow Forum, Management Science Laboratory, Department of Management Science and Technology, 9, 6-9.

Chrisman, J.J., Chua, J.H. \& Sharma, P. (1998). Important attributes of successors in family businesses: An exploratory study. Family Business Review, $11,19-34$.

De Alwis, A.Ch. (2016). Incumbents Influence on Family Business Succession Process. European Journal of Business and Management, 8(13), 96-105.

Decker, C., Heinrichs, K., Jaskiewicz, P. \& Rau, S.B. (2017). What do we know about succession in family businesses? Mapping current knowledge and unexplored territory. In: F.W. Kellermanns \& F. Hoy (eds). The Routledge Companion to Family Business, 15-44. New York, NY: Routledge. 
De Massis, A., Chua, J.H. \& Chrisman, J.J. (2008). Factors preventing intrafamily succession. Family Business Review, 21(2), 183-199, doi:10.1111/ j.1741-6248.2008.00118.x.

De Pontet, B.S., Wrosch, C. \& Gagne, M. (2007). An Exploration of the Generational Differences in Levels of Control Held Among Family Businesses Approaching Succession. Family Business Review, 20(4), 337-354, https:// doi.org/10.1111/j.1741-6248.2007.00103.x.

Déniz Déniz, M.C \& Cabrera-Suárez, M.K. (2005). Corporate Social Responsibility and Family Business in Spain. Journal of Business Ethics, 56 (1), 27-41.

Dumas, C., Dupuis, J.P., Richer, F. \& St.-Cyr, L. (1995). Factors that influence the next generation's decision to take over the family farm. Family Business Review, 8, 99-120.

Dyck, B., Mauws, M., Starke, F.A. \& Mischke, G.A. (2002). Passing the baton: The importance of sequence, timing, technique and communication in executive succession. Journal of Business Venturing, 17(2), 143-162, doi:10.1016/S0883-9026(00)00056-2.

Dyer, W.J. (1986). Cultural change in family business: Anticipating and managing business and family transitions. San Francisco, CA: Jossey-Bass.

Dyer, W.J. (1988). Culture and Continuity in Family Firms. Family Business Review, 1(1), 37-50.

Eisenhardt, K.M. (1989). Agency theory: An assessment and review. Academy of Management Review, 14, 57-74.

Evert, R.E., Martin, J.A., McLeod, M.S. \& Payne, G.T. (2015). Empirics in family business research: Progress, challenges, and the path ahead. Family Business Review, 29(1), 17-43.

Georgiou, T. \& Vrontis, D. (2013). Wine sector development: a conceptual framework toward succession effectiveness in family wineries. Journal of Transnational Management, 18(4), 246-272.

Glinka, B. (2008). Kulturowe uwarunkowania przedsiębiorczości, Warszawa: PWE.

Goldberg, S.D. \& Wooldridge, B. (1993). Self-Confidence and Managerial Autonomy: Successor Characteristics Critical to Succession in Family Firms. Family Business Review, 6(1), 55-73.

Goldberg, S.D. (1996). Research Note: Effective Successors in Family-Owned Businesses: Significant Elements. Family Business Review, 9(2), 185-197, https://doi.org/10.1111/j.1741-6248.1996.00185.x.

Goto, T. (2006). Longevity of Japanese family firms. In: P.Z. Poutziouris, K.X. Smyrnios \& S.B. Klein (eds.). The Handbook of Research on Family Business. Cheltenham, UK: Edward Elgar, 517-536. 
Griffeth, R.W., Allen, D.G. \& Barrett, R. (2006). Integration of family-owned business succession with turnover and life cycle models: Development of a successor retention process model. Human Resource Management Review, 16(4), 490-507, https://doi.org/10.1016/j.hrmr.2006.08.006.

Hadryś-Nowak, A. \& Więcek-Janka, E. (2016). Sukcesja kobiet w przedsiębiorstwach rodzinnych - wstępne wyniki badań, Przedsiębiorczość i Zarzadzanie, XVII/6/III, 35-47.

Hall, A. (2003). Strategising in the Context of Genuine Relations: An Interpretative Study of Strategic Renewal Through Family Interactions, JIBS Dissertation Series, 18.

Handler, W.C. (1992). The Succession Experience of the Next Generation, Family Business Review, 5(3), 283-307.

Handler, W.C. (1994). Succession in family business: A review of the research. Family Business Review, 7(2), 133-157.

Harveston, P.D., Davis, P.S., Lyden, J.A. (1997). Succession Planning in Family Business: The Impact of Owner Gender. Family Business Review, 10(4), 373-396, https://doi.org/10.1111/j.1741-6248.1997.00373.xiurship.

Helsen, Z., Lybaert, N., Steijvers, T., Orens, R. \& Dekker, J. (2017). Management Control Systems In Family Firms: A Review Of The Literature And Directions For The Future. Journal of Economic Surveys, 31(2), 410-435.

Hofstede, G. (1980). Culture's consequences: International differences in workrelated values. Beverly Hills: Sage Publications, Inc.

Howorth, C. \& Ali, A.Z. (2001). Family Business Succession in Portugal: An Examination of Case Studies in the Furniture Industry. Family Business Review, 14(3), 231-244, doi: 10.1111/j.1741-6248.2001.00231.x.

Inglehart, R. (1988). The Renaissance of Political Culture. The American Political Science Review, 82(4), 1203-1230.

Johns, G. (2006). The Essential Impact of Context on Organizational Behavior. The Academy of Management Review, 31(2), 386-408.

Karima, M. \& Habib, A. (2012). Determinants of Intention and Succession Planning in Tunisian Family Business. International Journal of Business and Social Science, 3(12), 118-133.

Kelly, L., Athanassiou, N. \& Crittenden, W. (2000). Founder centrality and strategic behavior in the family-owned firm. Entrepreneurship Theory and Practice, 25(2), 27-42.

Kepner, E. (1983). The family and the firm: a coevolutionary perspective. Organizational Dynamics, 12(1), 57-70.

Kibler, E. (2013). Formation of Entrepreneurial Intentions in a Regional Context. Entrepreneurship and Regional Development, 25(2-3), 293-323, doi: 10.1080/08985626.2012.721008. 
Kostera, M. (1996). Postmodernizm w zarzadzaniu. Warszawa: PWE,

Kotler, Ph. \& Armstrong, G. (2011). Principles in marketing, New York: Pearson Prentice Hall.

Kuratko, D., Hornsby, J. \& Montagno, R. (1993). Family business succession in Korean and US firms. Journal of Small Business Management, 31(2), 132.

Lambrecht, J. (2005). Multigenerational transition in family businesses: A new explanatory model. Family Business Review, 18(4), 267-282, doi:10.1111/ j.1741-6248.2005.00048.x.

Le Breton-Miller, I., Miller, D. \& Steier, L.P. (2004). Toward an integrative model of effective FOB succession. Entrepreneurship Theory and Practice, $28,305-328$.

Lee, J. (2006). Impact of family relationships on attitudes of the second generation in family business. Family Business Review, 19(3), 175-191, doi:10.1111/j.1741-6248.2006.00069.x.

Lee, K.S., Lim, G.M. \& Lim, W.S. (2003). Family business succession: Appropriation risk and choice of successor. Academy of Management Review. 28, 657-666.

Levenburg, N.M., Wolterink, T.D. \& Subramanian, R. (2003). MetalBenders Industries, Inc.: The accidental entrepreneur. Case Research Journal, 23(4), $115-134$.

Malone, S.C. (1989). Selected Correlates of Business Continuity Planning in the Family Business. Family Business Review, 2(4), 341-353, https://doi. org/10.1111/j.1741-6248.1989.tb00003.x.

Marjański, A. \& Sułkowski, Ł. (2019). The Evolution of Family Entrepreneurship in Poland: Main Findings Based on Surveys and Interviews from 2009-2018. Entrepreneurial Business and Economic Review, 7(1), doi: 10.15678/EBER.2019.070106.

Meyer, J.P. \& Allen, N.J. (1991). A three-component conceptualization of organizational commitment. Human Resource Management Review, 1, 61-89.

Meyer, J.P. \& Herscovitch, L. (2001). Toward a general model of commitment. Human Resource Management Review, 11(3), 299-326.

Mierzal, L., Ritz, J., Torres, G.L.F. \& Bergfeld M.M. (2017). Succession Planning in Different Cultures: A Comparative Analysis of Family Firms in Mexico and Germany. Munich: Munich Business School.

Morck, R. \& Yeung, B. (2003). Agency Problems in Large Family Groups. Entrepreneurship: Theory and Practice, 27(4), 367-382, doi: 10.1111/1540-8520. t01-1-00015.

Morris, M.H., Williams, R.W., Allen, J.A. \& Avila, R.A. (1997). Correlates of success in family business transitions. Journal of Business Venturing, 12, 385-401.

Neubauer, H. (2003). The dynamics of succession in family business in western European countries. Family Business Review, 16, 269-281. 
Nordqvist, M., Wennberg, K., Bau, M. \& Hellerstedt, K. (2013). An entrepreneurial process perspective on succession in family firms. Small Business Economics, 40(4), 1087-1122.

Pawlak, A. (2014). Sukcesja w polskich przedsiębiorstwach rodzinnych, Przedsiębiorczość i zarzadzanie, XV/7/I, 71-82.

Pyromalis, V.D. \& Vozikis, G.S. (2009). Mapping the successful succession process in family firms: Evidence from Greece; International Entrepreneurship and Management Journal, 5(4), 439-460, doi: 10.1007/s11365-009-0118-3.

Robbins, S.P. \& Judge, T.A. (2012). Essentials of Organizational Behavior, $11^{\text {th }} \mathrm{ed}$. Harlow, Essex: Pearson Education Inc.

Royer, S., Simons, R., Boyd, B. \& Rafferty, A. (2008). Promoting family: A contingency model of family business succession. Family Business Review, 21(1), 15-30, doi:10.1111/j.1741-6248.2007.00108.x.

Safin, K. (2007). Przedsiębiorstwa rodzinne, istota i zachowania strategiczne. Wrocław: Wydawnictwo Akademii Ekonomicznej.

Schmitt, A. \& Frese, M. (2011). Family Involvement in Chinese And German Small Businesses. Journal of Enterprising Culture, 19(3), 261-285, doi: 10.1142/S0218495811000775.

Schröder, E., Schmitt-Rodermund, E. \& Arnaud, N. (2011). Career choice intentions of adolescents with a family business background. Family Business Review, 24(4), 305-321.

Sharma, P. \& Rao, S. (2000). Successor attributes in Indian and Canadian family firms: A comparative study. Family Business Review, 13, 313-330.

Sharma, P., Chrisman, J.J., Pablo, A.L. \& Chua, J.H. (2001). Determinants of initial satisfaction with the succession process in family firms: A conceptual model. Entrepreneurship Theory and Practice, 25(3), 17-35, https://doi. org/10.1177/104225870102500302.

Sharma, P., Chrisman, J.J. \& Chua, J.H (2003). Succession Planning as Planned Behavior: Some Empirical Results. Family Business Review, 16(1), doi: 10.1111/j.1741-6248.2003.00001.x.

Sharma, P. \& Chua, J.H. (2013). Asian family enterprises and family business research. Asia Pacific Journal of Management, 30, 641-656, doi: 10.1007/ s10490-013-9350-z.

Sharma, P. (2004). An overview of the field of family business studies: Current status and directions for the future. Family Business Review, 17(1), 1-36, doi:10.1111/j.1741-6248.2004.00001.x.

Sharma, P. \& Irving, P.G. (2005). Four bases of family business successor commitment: Antecedents and consequences. Entrepreneurship Theory and Practice, 29(1), 13-33. 
Stavrou, E. (1999). Succession in family businesses: Exploring the effects of demographic factors on offspring intentions to join and take over the business. Journal of Small Business Management, 37(3), 43-62.

Sułkowski, Ł. (red.). (2005). Determinanty rozwoju przedsiębiorstw rodzinnych $w$ Polsce. Torun: Towarzystwo Naukowe Organizacji i Kierownictwa „Dom Organizatora".

Sułkowski, Ł. (2008). Czy warto zajmować się kulturą organizacyjną, Zarzqdzanie Zasobami Ludzkimi, 6, 9-25.

Sułkowski, Ł. \& Marjański, A. (2011). Firmy rodzinne. Jak osiagnać sukces w sztafecie pokoleń. Warszawa: Wydawnictwo Poltext.

Sułkowski, Ł. (2013). Identity, Culture and Values of Family SME in Poland. In: M.R. Contreras Loera, Ł. Sułkowski \& A. Marjański (eds.). Development of small and medium-sized enterprises - an international perspective, 11-23. Sinaloa-Łódź: Universiad De Occidente, Sinaloa, MexicoSpołeczna Akademia Nauk.

Tatoglu, E., Kula, V. \& Glaister, K.W. (2008). Succession planning in family-owned businesses: Evidence from Turkey. International Small Business Journal, 26(2), 155-180, doi:10.1177/0266242607086572.

Thompson, K.R. \& Luthans, F. (1990), Organisational Culture. A Behavioural Perspective. In: Organisational Climate and Culture, Schneider, B. (ed.). Oxford, UK: Jossey-Bass.

Tripopsakul, S. (2018). Entrepreneurial Perceptions and Intentions: The Comparative Study Between Poland and Thailand. Polish Journal Of Management Studies, 17( 1), 249-259.

Van der Merwe, S., Venter, E. \& Ellis, S.M. (2009). An exploratory study of some of the determinants of management succession planning in family businesses. Management Dynamics. Journal of the Southern African Institute for Management Scientists, 18(4), 2-17.

Venter, E., Boshoff, C. \& Maas, G. (2005). The Influence of successor-related factors on the succession process in small and medium-sized family businesses. Family Business Review, 18(4), 283-303, doi:10.1111/j.1741-6248.2005.00049.x.

Vera, C.F. \& Dean, M.A. (2005). An Examination of The Challenges Daughters Face in Family Business Succession. Family Business Review, 18(4), 321-345.

Von Bertalanffy, L. (1972). The History and Status of General Systems Theory. The Academy of Management Journal, 15(4), 407-426.

Ward, J.L. (2000). Reflections on Indian Family Groups. Family Business Review, 13(2), 271-278.

Ward, J.L. (2011). Keeping the family business healthy: How to plan for continuing growth, profitability, and family leadership. New York: Palgrave Macmillan. 
Weber, M. (1905). The Protestant Ethic and the Spirit of Capitalism. New York: Routledge.

Więcek-Janka, E., Mierzwiak, R. \& Kijewska, J. (2015). Taxonomic Approach to Competencies in the Succession Process of Family Firms with the Use of Grey Clustering Analysis, Conference GSIS, doi: 10.1109/GSIS.2015.7301896.

Yan, J. \& Sorensen, R. (2006). The effect of Confucian values on succession in family business. Family Business Review, 19, 235-250.

Zellweger, T., Sieger, P. \& Halter, F. (2011). Should I Stay or Should I Go? Career Choice Intentions of Students with Family Business Background. Journal of Business Venturing, 26(5), 521-536. 


\title{
KULTUROWE UWARUNKOWANIA SUKCESJI W FIRMACH RODZINNYCH Z PERSPEKTYWĄ NASTĘPCÓW
}

\begin{abstract}
Abstrakt
Tło. Sukcesja to najczęściej badane zagadnienie dotyczące firm rodzinnych. Wiadomo, że by poznać dane zjawisko musimy zrozumieć jego specyfikę, mechanizm działania, uwarunkowania i konsekwencje. W odniesieniu do sukcesji jak dotychczas intensywnie badano uwarunkowania tego procesu, z tym, że główny nurt dociekań zdaje się koncentrować na określonych zagadnieniach i pomijać niektóre istotne aspekty tego problemu.

Cele badawcze. Celem niniejszego badania jest synteza dotychczasowej wiedzy o uwarunkowaniach sukcesji oraz identyfikacja ewentualnych luk w badaniach, a tym samym potencjalnych obszarów przyszłych badań, Dociekania koncentrują się na kulturze, w obrębie której funkcjonują firmy jako potencjalnie istotnym czynniku determinującym zachowanie aktorów zaangażowanych w proces sukcesji.
\end{abstract}

Metodologia. Dyskusja zaprezentowana w artykule ma charakter teoretyczny i jest oparta na dedukcji. Determinanty sukcesji sa poddane syntezie na podstawie dotychczasowych badań tego zagadnienia. Jako że nie ma sukcesji bez sukcesora, badanie jest realizowane z uwzględnieniem perspektywy młodszego pokolenia, tak by uwzględnić kompleksowy charakter badanego zjawiska.

Kluczowe wnioski. W efekcie przeprowadzonych studiów zidentyfikowano istotne luki w dotychczasowych badaniach sukcesji w firmach rodzinnych w obszarze uwarunkowań kulturowych oraz wskazano na zasadność prowadzenia międzykulturowych studiów porównawczych dla poznania procesu sukcesji. Wyniki badań mają również swoje szersze konsekwencje, bowiem potwierdzają możliwość różnicowania zachowań organizacji w zależności od uwarunkowań kulturowych i tym samym podważają uniwersalny charakter stwierdzeń opartych na badaniach realizowanych w określonej kulturze.

Słowa kluczowe: firmy rodzinne, sukcesja, sukcesor, kultura narodowa, młode pokolenie, zaangażowanie, komunikacja międzypokoleniowa. 